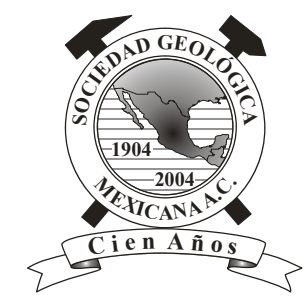

\title{
Sea level changes through the Jurassic/Cretaceous boundary in western Cuba indicated by taphonomic analysis
}

\author{
Rafael Antonio López Martínez ${ }^{1, *}$, Ricardo Barragán Manzo ${ }^{1}$, \\ Blanca Estela Margarita Buitrón Sánchez ${ }^{1}$, Reynaldo Rojas Consuela ${ }^{2}$ \\ ${ }^{1}$ Instituto de Geología, Universidad Nacional Autónoma de México, Ciudad Universitaria, Delegación Coyoacán, C.P. 04510, México \\ D.F., México. \\ ${ }^{2}$ Museo Nacional de Historia Natural de Cuba, Obispo 61, C.P. 1100, La Habana, Cuba. \\ *rafaelopez83@hotmail.com
}

\begin{abstract}
The taphonomical and microfacies analyses of the Guasasa Formation in the San Vicente section of western Cuba, allowed the recognition of regional sea level fluctuations through the Jurassic/Cretaceous transition. Four discrete taphofacies associated with different depositional conditions were characterized through the section. The paleoecological conditions reconstruction of indicates that the site of deposition changed from a shallow water carbonate bank recognizable at the base of the section (late Tithonian facies of the San Vicente Member) into a deep-water basinal environment at its top through the Berriasian, as facies of the overlying El Americano member. This continuous deepening of the basin was interrupted only by a short-term sea level drop close to the Jurassic/ Cretaceous boundary.
\end{abstract}

Keywords: Jurassic-Cretaceous boundary, taphonomy, sea level changes, paleoecology.

\section{Resumen}

El análisis tafonómico y de microfacies de la Formación Guasasa, en la sección San Vicente del oeste de Cuba, permitió el reconocimiento de fluctuaciones regionales del nivel del mar a través del límite Jurásico/Cretácico. En la sección se caracterizaron cuatro tafofacies asociadas a diferentes condiciones de depósito. La reconstrucción de las condiciones paleoecológicas indica que el sitio de depósito comenzó como un banco carbonatado de aguas someras en la base de la sección (facies del Tithoniano superior de la Formación San Vicente) con una transición a facies profundas de cuenca hacia el techo, (facies del Berriasiano correspondientes al miembro El Americano). Esta profundización continua fue interrumpida sólo por un corto episodio de descenso del nivel del mar cercano al límite Jurásico/Cretácico.

Palabras clave: Limite Jurásico-Cretácico, tafonomía, cambios del nivel del mar, paleoecología. 


\section{Introduction}

The term taphonomy, as applied to fossilization processes, was first used by Efremov (1940) to describe "the study of the transition of organic remains from the biosphere into the lithosphere". Since then, many works have been published and new terms have been proposed to describe the different aspects of the fossilization process. Up to date taphonomical studies are crucial to understand the complex processes involved in the transmission of information from the biosphere into the lithosphere (Fernández-López, 1984, 1988; Tasch, 1973). Thus, the taphonomical characterization of a fossil assemblage plays an important role towards their paleobiological, paleoecological and biostratigraphical interpretations (Fernández-López, 1991b). Taphonomical processes can be divided into two main stages (FernándezLópez, 1991a): 1) The biostratinomical stage (Weigelt, 1927), which groups the events that occurred after the production of entities (death or production in case of fossil traces), and 2) The fossildiagenetic stage (Müller, 1951), which embraces all processes that happened after burial of produced entities. The present work focuses on the taphonomical characterization of facies of a Late Jurassic/ Early Cretaceous stratigraphic succession from western Cuba, to unravel the main depositional and paleoecological processes that took place through that geological interval on a regional scale.

\section{Regional geological settings}

Western Cuban Jurassic/Cretaceous rocks are mainly exposed in the Sierra de los Órganos Belt (Figure 1). Those rocks are recorded in the Guasasa Formation (Herrera, 1961), a formal unit subdivided into four members (older to younger): San Vicente, El Americano, Tumbadero, and Tumbitas (Figure 2). The studied section includes rocks of the upper part of the San Vicente, and the whole of the El Americano and Tumbadero members.

The San Vicente member (Herrera, 1961) is mainly composed of karstified light gray massive limestone. A lithologic change is evident at the top of the unit where the

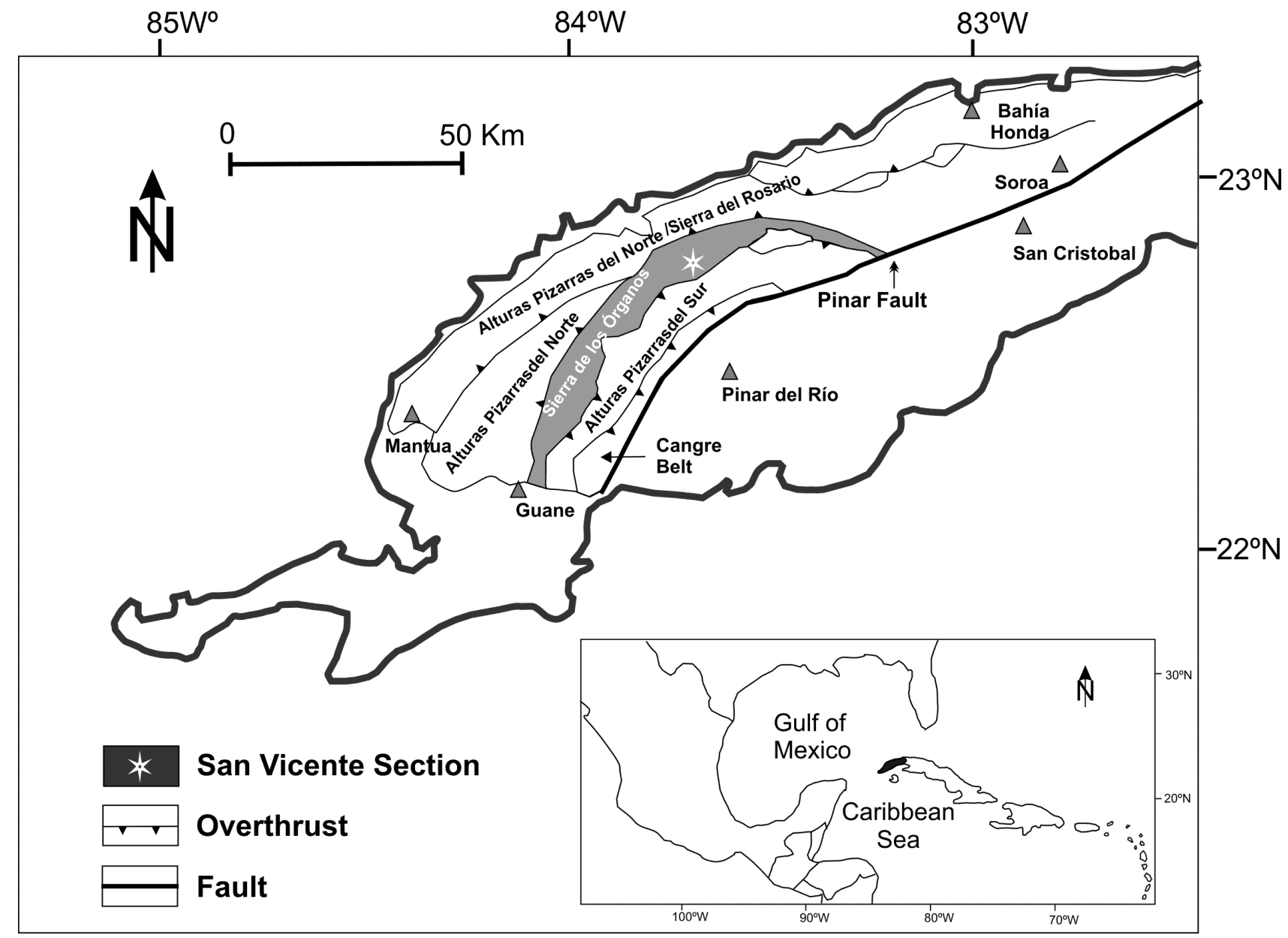

Figure 1. Map of western Cuba showing the location of the studied area and the main geological structures. Modified from Cobiella-Reguera and Olóriz (2009). 


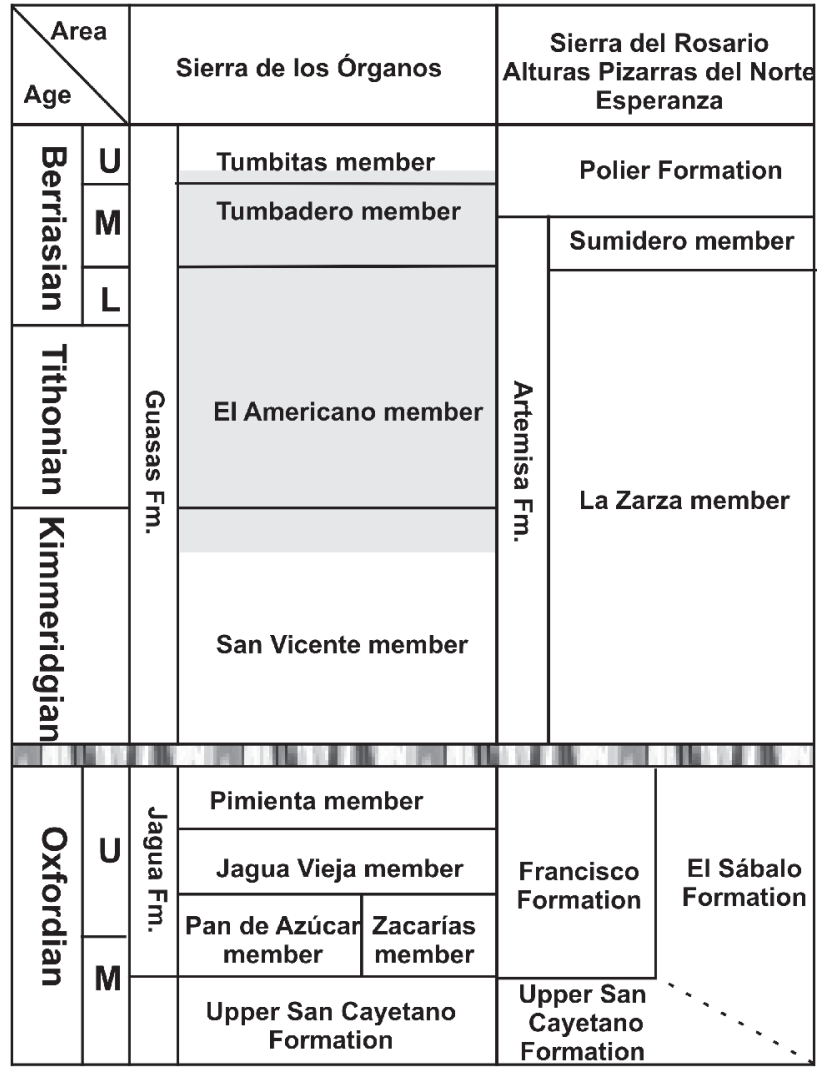

Figure 2. Stratigraphy of the Sierra de los Órganos Belt. The studied portion is shadowed. Partially modified from Cobiella-Reguera and Olóriz (2009).

calcareous beds become thin and blackish in color. This lithological change marks the gradual transition to the record of the El Americano member. The contact between the El Americano and the Tumbadero members is marked by the sudden appearance of discrete chert lenses. The uppermost Tumbitas member is identified through the disappearance of chert and is represented in the studied section only by its basal beds.

\section{Material and methods}

A bed-by-bed sampling provided the material for 160 thin sections. Each sample was studied under a petrographic microscope up to a minimum of 100 visual counts.

Taphonomical processes were interpreted in order to define the different preservation stages (accumulated, resedimented or elaborated entities), following the guidelines of Fernández-López (1984, 1986, 1988, 1991a, b).

Furthermore, different microtaphonomic features, such as the fragmentation degree, were analyzed in order to calculate the fragmentation index (Fi) (Olóriz et al., 2004). The fragmentation degree is a qualitative characterization of the fossil specimens, it represents their current deviation from their original morphology, and can be divided into three levels: high (HFD), medium (MFD) and lower (LFD) (Olóriz et al., 2004).

The fragmentation index is the result of an analysis of the fragmentation degree to a set of specimens and is calculated as follows (Olóriz et al., 2002) (Equation 1):

$$
\mathrm{Fi}=\frac{[(n H F D \times 100)+(n M F D \times 50)+(n L F D \times 1)]}{N}
$$

Where $n$ is the corresponding number of specimens assigned to each of the three different fragmentation degrees (HFD, MFD and LFD), and $N$ is the total number of specimens, studied in the sample.

The resedimentation rate is an expression of the percentage of resedimented entities within each sample. This index is calculated by counting and comparing the resedimented and the accumulated entities of the assemblage sample by sample.

To determine the variations in the paleobiological community various biodiversity indexes were analyzed. The species richness is a simple index obtained by counting the specimens of each species contained in the sample and plotting their relative abundance on circular diagrams for a visual estimation of the composition assemblage (Hammer and Harper, 2006).

Another index used is the Simpson dominance index (D) (Simpson, 1949), which indicates the probability that two randomly picked individuals belong to the same species. The mathematical expression of this index is as follows (Equation 2):

$$
D=\sum\left(p_{i}^{2}\right)
$$

where $p_{i=n_{i} / n}$ (the proportion of the species $i$ ).

If the Simpson dominance index is used, it is also meaningful to use the Simpson index of diversity $(S D i)$. The $S D i$ is a variation of the dominance index and it expresses the degree of diversity of the assemblage by the inverse of the dominance (Equation 3):

$$
S D i=1-D
$$

Finally, the Shannon-Weaver index expresses the entropy of the assemblage (Hammer and Harper, 2006) and is formulated as (Equation 4):

$$
E=\sum p_{i \ln p_{i}}
$$

Where $p_{i}$ represents the same mathematical value used for the Simpson dominance index (D).

\section{Terminology and tools for a taphonomic analysis}

The study of the different microtaphonomic features in thin sections allowed the classification of entities into three mechanical conservational states:

Accumulated: These entities remain at the place of their paleobiological production. Different benthic foraminifers and algal mats in growth position provide a good example to define this mechanical conservational stage.

Resedimented: These entities are penecontemporaneous 
with the accumulated entities but were displaced across the sea floor after accumulation and prior to their final burial (Fernández-López, 1991b). The preferred orientation of their components and their sorting degree are good reference points to recognize transported entities.

Re-elaborated: These entities are different in age when compared with the resedimented and the accumulated entities recorded in the same topological position. In calpionellid assemblages it is difficult to discern this type of conservational state (except in markedly diachronic specimens), due to the small size and the lack of characteristics such as abrasion. In the studied samples herein, no significant age gaps were found. However, the presence of a lithified matrix filling cavities of some elements provides a good point in support of an early lithification process (Figure 3A\%.

\section{Taphonomic processes and interpretation}

The taphonomical processes were grouped in two main stages as follows:

\subsection{Biostratinomical stage}

\subsubsection{Necrokinesis}

Every planktonic organism must experience postmortem transport by definition, as it settles, through the water column, to the sea floor. The currents can transfer dead (or living) organisms to distant regions far away from their original habitat.

In the studied samples, sorting and reorientation were used as current transport indicators. If size selection did not occur, then a minimal transport is assumed and the entities are considered to be in situ. On the other hand, if size selection or reorientation is present, a certain degree of current transport is assumed. Other criteria to assume current action are recognized in thin section, such as concave up shells and other geopetal structures (Figure 3B, C).

Due to the small size of calpionellids and radiolarians in the studied samples, it has proven very difficult to discern between accumulated, resedimentated and even re-elaborated assemblages. Since no sign of re-elaborated processes were recognized in radiolarians and calpionellids, they are assumed to be accumulated, even when necrokinesis actually occurred, reflecting in consequence the true paleoecological conditions.

\subsubsection{Resedimentation}

Resedimentation represents the most important process in the studied section. Currents carry dead (or alive) entities, accumulating them at other sites far away from their initial locations.

This process introduces allochthonous entities into the autochthonous assemblage. If no distinction is made, the paleoecological inferences can be erroneous.
Many juvenile shallow water gastropods with different degrees of fragmentation, incrustation, or even in a well-preservation state are present within a typical deep water assemblage. This phenomenon was interpreted by Pszczólkowski and Myczynski (2010) as a period of low oxygenation levels. However, the size classification, the presence of only juvenile specimens, and processes such as fragmentation and incrustation by bryozoans, suggest a permanence in the Taphonomic Active Zone (TAZ) (Farinati et al., 2005) in shallow waters, posteriorly transported and then subjected to final burial in the deep water environment (Figure 3D). For this reason we can define this as a mixed association (Fernández-López, 1984).

The resedimentation varies through the section and is linked with a tectonically influenced dynamic sea. In a chronological succession, maximum resedimentation intensity occurs in the San Vicente member and the beds related to its drowning (uppermost San Vicente member and lowermost El Americano member).

As soon as equilibrium was established, the resedimentation rate decreased and increased only in storm deposits. The resedimentation rate is linked with waves and current influence and is inversely proportional to sedimentation depth and shore line distance.

As soon as equilibrium was established, the resedimentation rate decreased and increased only in storm deposits. The resedimentation rate is linked with waves and current influence and is inversely proportional to sedimentation depth and shore line distance.

\subsubsection{Disarticulation}

As a general rule, the saccocomids were preserved as highly disarticulated and densely packed entities (Figure $3 \mathrm{E})$. The high taphonomic redundancy and replication of these elements caused associations with a high dominance index. Similar deposits were interpreted by Kuhry et al. (1976) as linked to primary carbonated bank obliteration after drowning and closely related with current action.

\subsubsection{Reorientation}

This process was recognized mainly by two factors. One consists of a bioestratinomical process and is related to the action of currents and occurs mainly in saccocomids, filaments, and sponge spicules. The second one is related to diagenesis and consists of the orientation of fossils in laminar arrangements.

\subsubsection{Fragmentation}

This is an important characteristic employed to discern the hydrodynamic conditions and permanence of a particular entity in the Taphonomic Active Zone (TAZ) (Farinati et al., 2005). In the studied section, entities with the three fragmentation degrees. High, medium and low, were recognized. Figures 3F, G show gastropods with low and high fragmentation degrees respectively. 


\subsubsection{Encrustation}

The action of encruster organisms is recorded along the section but is particularly abundant at the top of the San Vicente and the base of the El Americano members. The main encruster organisms recognized are benthic foraminifers and bryozoans. See also Figure 3D.

\subsubsection{Condensation}

This is a wide term that includes both sedimentary and taphonomic condensation (Fernández-López, 1991c). Both types were recognized in the present work.

Sedimentary condensation: The presence of glauconite in the section (Figure $3 \mathrm{H}$ ) suggests a low sedimentation rate in the lower part of the El Americano member. The glauconitic levels are usually interpreted as indicators of condensed sections (Akihisa, 1998; Kelly and Webb, 1999). A truly condensed section is defined by the overlap of two or more biozones in its record (Gómez and FernándezLópez, 1994). In the studied section, the subdivision of the Crassicollaria zone was not possible due to the mixture of specimens of the different biozones that included Remanei, Colomi and Brevis subzones.

This condensation level along with glauconite remnants occurs in the lowermost part of the El Americano member just above the flooded San Vicente carbonated bank and is interpreted as the maximum flooding surface of a drowning event.

\subsubsection{Taphonomic condensation}

This is a concept similar to sedimentary condensation but is defined by Fernández-López (1991c) as the mixture of fossils of two or more biozones, not necessarily due to a low sedimentary rate. A good example is represented by tempestite condensation levels (Fernández- López, 1991c). Those levels include material from different biozones but were deposited in a rapid sedimentation process. In the studied section a dramatic increase of tempestitic levels with taphonomic condensation occurs near the Jurassic/ Cretaceous boundary. This phenomenon is interpreted as a sedimentary response to a global sea level drop proposed by different authors (Seilacher, 1982; Hagdorn, 1982).

\subsubsection{Microboring}

This is an important taphonomic process in the studied section, particularly abundant in the lower part of the El Americano member. The process creates the micro restricted environment necessary for the glauconitization process (McRae, 1972) (Figure 3H, I).

\subsection{Fossildiagenetic stage}

\subsubsection{Neomorphism}

This process occurs in the early diagenesis and is very important for the conservation of entities. In the studied section it is common fundamentally in mollusk shells (Figure 3J).

\subsubsection{Replacement}

The replacement of the original composition was recorded in two main forms. One consisting of the replacement of radiolarian siliceous tests by calcite (Figure $3 \mathrm{~K}$ ), and another marked by the replacement of original calcite structures by glauconite (Figure $3 \mathrm{H}, \mathrm{I}, \mathrm{L}$ ).

\subsubsection{Dissolution}

The process can be observed in the sections with many shell remains, mainly those with an original aragonite composition. It is particularly frequent and intense on ammonite shells (Figure 4A).

\subsubsection{Silicification}

Even though this process plays an important role in the conservation of the entities, in the studied section, its influence works against their preservation. The main reason for its destructive action is due to the fact that silicification is related to oxidation processes and the formation of goethite (Figure 4B).

\subsubsection{Re-elaboration}

The re-elaborated entities are present along the whole section, being more abundant in its lower part. A good criterion to define these entities is the presence of ancient lithified matrix within their structures. Re-elaborated ostracods preserve part of filled matrix when transport occurs and accumulate like intraclasts in a younger assemblage. A re-elaborated specimen is shown in Figure 3A.

\section{Taphofacies (TF1 - TF4)}

The influence of distinctive taphogenic processes was taken into account in stratigraphical order to separate the different taphofacies:

TF.1: Mainly consists of wackestone-packstone of peloids with abundant Favreina sp. (Figure 4C, D), green algae, ostracods, mollusks shells, benthic foraminifers and scarce calcispheres. The main taphogenic processes are bioturbation, resedimentation, fragmentation, neomorphism, microboring and orientation.

The presence of Favreina sp. (Figure 4C, D) is a peculiar attribute in this taphofacies. The ichnogenus Favreina is related to Thalassinidae and is interpreted by some authors to be crustacean coprolites (Kietzmann and Palma, 2010). The mass accumulations of Favreina are very common in the Late Jurassic-Early Cretaceous shallow water carbonates (Flügel, 2004) and are reported from the outer ramp, and deep sea environments (De Romero and GaleaAlvarez, 1995; Schweigert et al., 1997). Different types of Favreinids are common on facies of the San Vicente member. Classification of those ichnofossils is out of the scope of the present contribution. Nonetheless, their record suggests the presence of soft bottom dwellers in an oxic and 

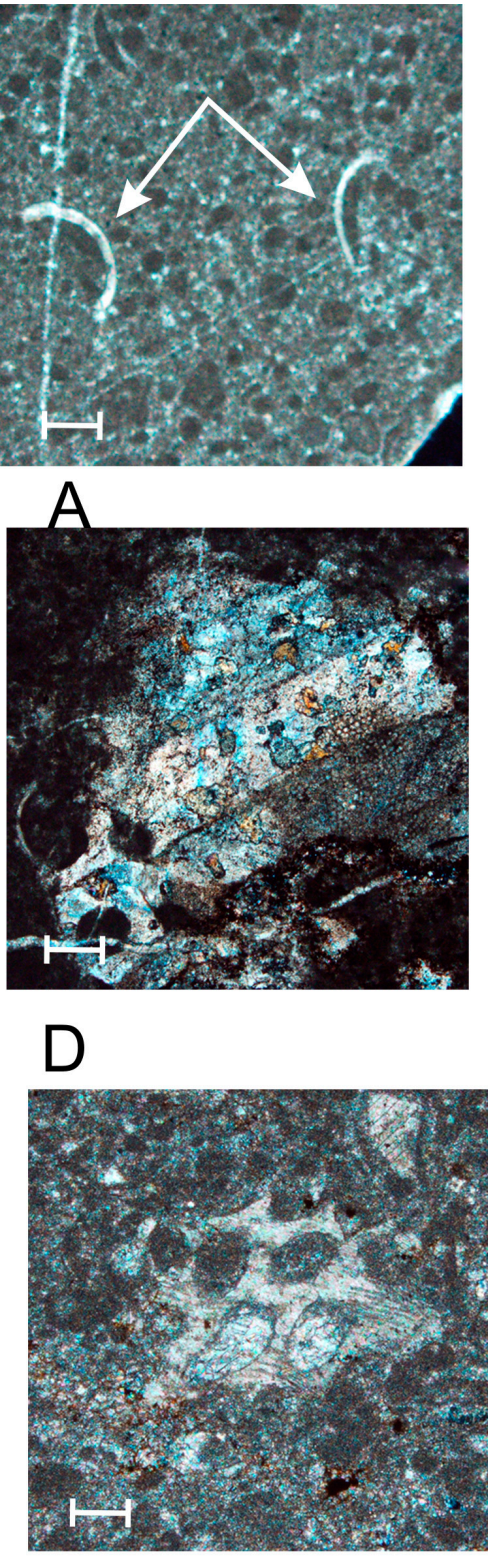

G
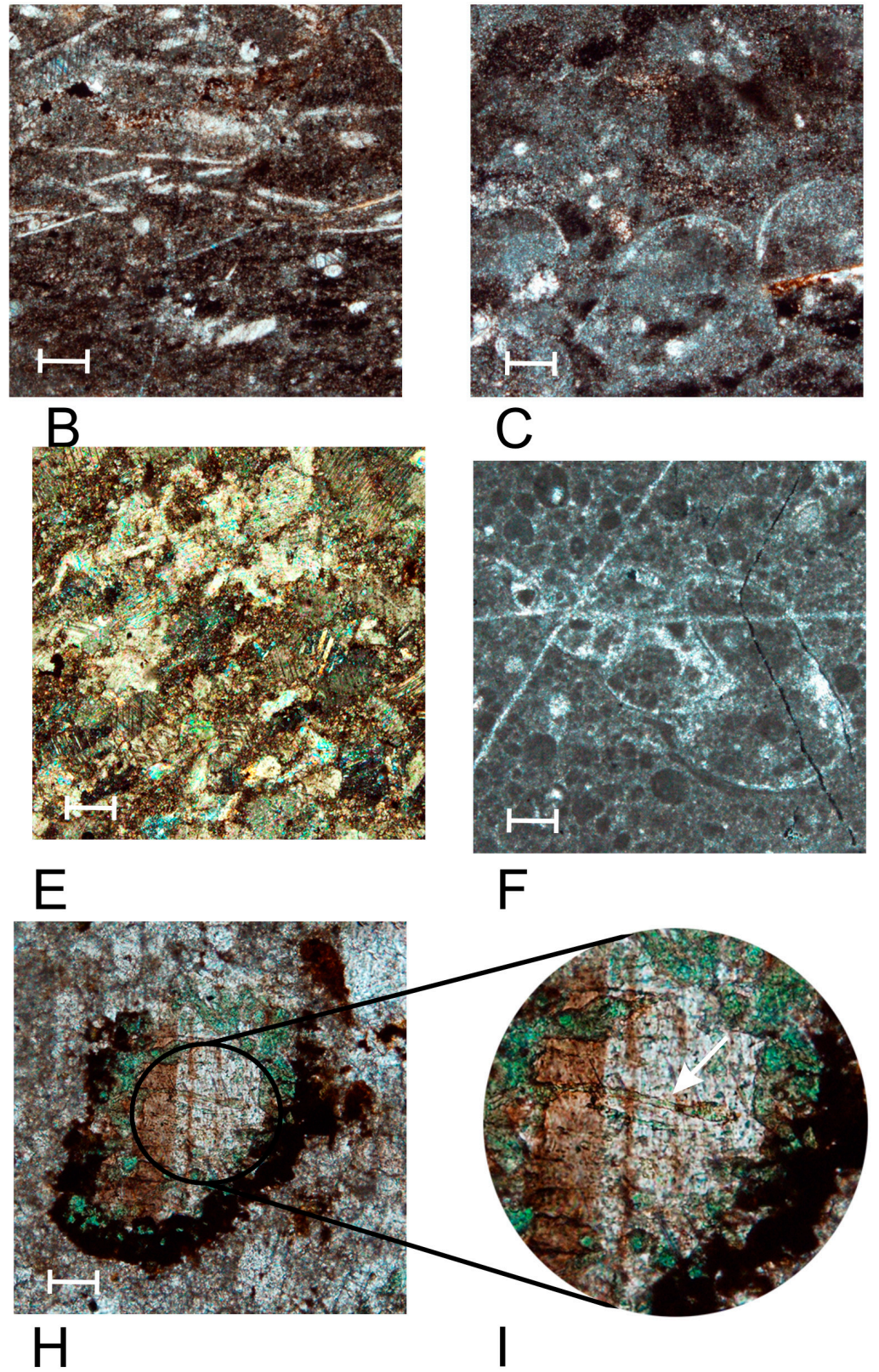

$\mathrm{F}$
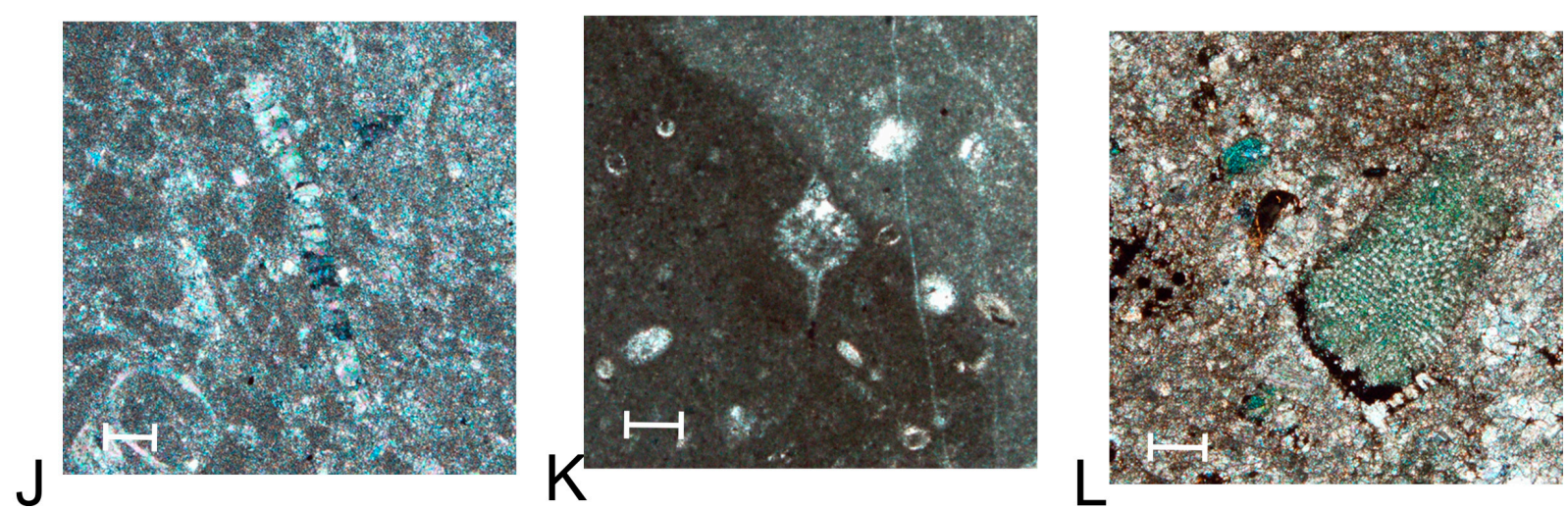

Figure 3. Main taphonomical features. A: Reworked ostracods with partially lithified matrix before transport and final burial; B: Orientated filaments with incipient cross stratification; C: Concave up shells of ostracods; D: Gastropod shell incrusted by bryozoans; E: Highly disarticulated and densely packed Soccocomids; F, G: Gastropods showing low and high fragmentation degrees respectively; H: Glauconitized remains; I: Microboring in equinoderm. Arrow shows the channel into the plate that allowed the glauconitization process; J: Neomorfism in pelecypod shell; K: Radiolarian test replaced by calcite; L: Replacement by glauconite. Scale bar: $150 \mu \mathrm{m}$. 


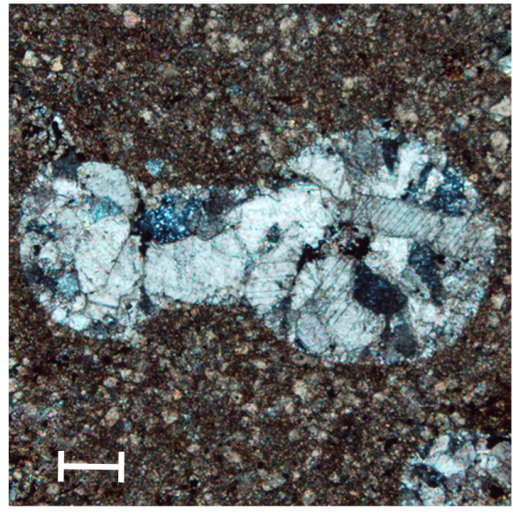

A
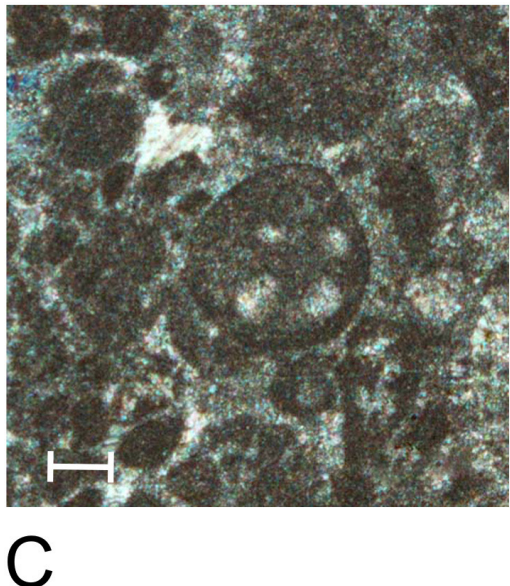

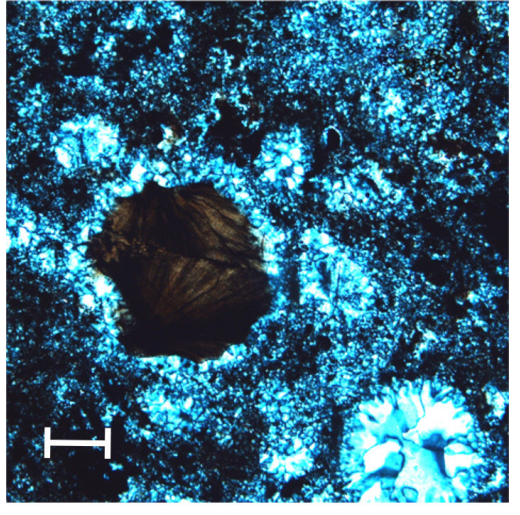

B
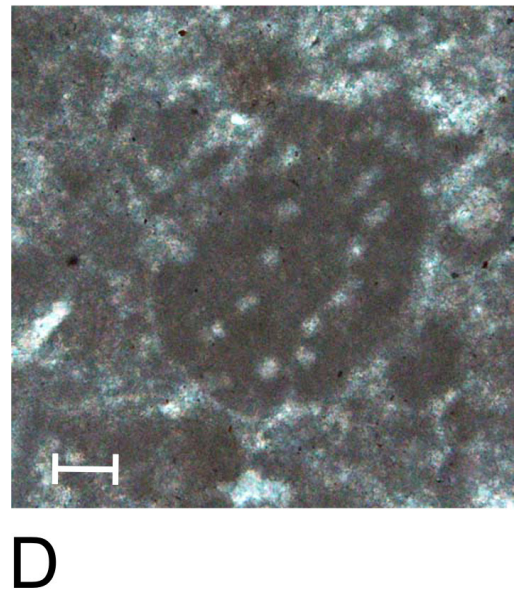

Figure 4. Main taphonomical features Part 2. A: Intense dissolution of an ammonite shell; B: Silicification and formation of goethite in radiolarian facies; C, D: Favreina sp. Scale bar: $150 \mu \mathrm{m}$.

nutrient-rich environment. The high fragmentation index of $55.29 \%$ (Figure 5) and the resedimentation rate indicate a high-energy environment near to the shoreline and directly influenced by the wave action.

TF.2: Mainly consists of packstone of coarse Saccocoma debris with scarce and highly recrystallized calpionellids and calcispheres. The taphonomic processes recorded are basically high fragmentation and degree of disarticulation, orientation, glauconite replacement, dissolution and microboring.

This taphofacies is close related to the drowning platform event. Abundance of Saccocoma and the appearance of calpionellids (Figure 5), indicate the sudden development of deep environmental conditions.

The high disarticulation degree, orientation of many Saccocoma arms fragments, high fragmentation index and the accumulation of coarse debris suggest transportation from adjacent areas after the drowning of the platform.

Another outstanding process in this taphofacies is the phosphatic replacement of some fossils, suggesting a slow sedimentation rate. This process was stronger in organisms that display good porosity like bryozoans (Figure 3H, I,
L), or in fragments that develop secondary porosity due to microboring.

The biodiversity indexes vary sharply. Species dominance increases whereas the Shannon and the Simpson indexes $(S D i)$ decrease. These types of indexes reflect paleocommunities generally associated with r-strategy organisms. In the studied section the dominance of Saccocoma is linked to the sudden appearance of pelagic conditions. Nonetheless, the interpretation of the paleocommunity indexes is difficult due to the high taphonomic replication and redundancy of saccocomids. If we assume that one saccocomid specimen could generate hundreds of arms, it is necessary to introduce a correction factor, and then the dominance of saccocomids is lower than that that reflected by calculated indexes. Nonetheless, crinoids are assumed to be a very important constituent of the paleocommunity. After the drowning of the carbonate bank (San Vicente member), new ecological niches started being colonized by pioneering organisms like saccocomids.

TF.3: Consists of wackestone-packstone of calpionellids with calcispheres and other microfossils. The main taphonomic processes consist of pyritization, 


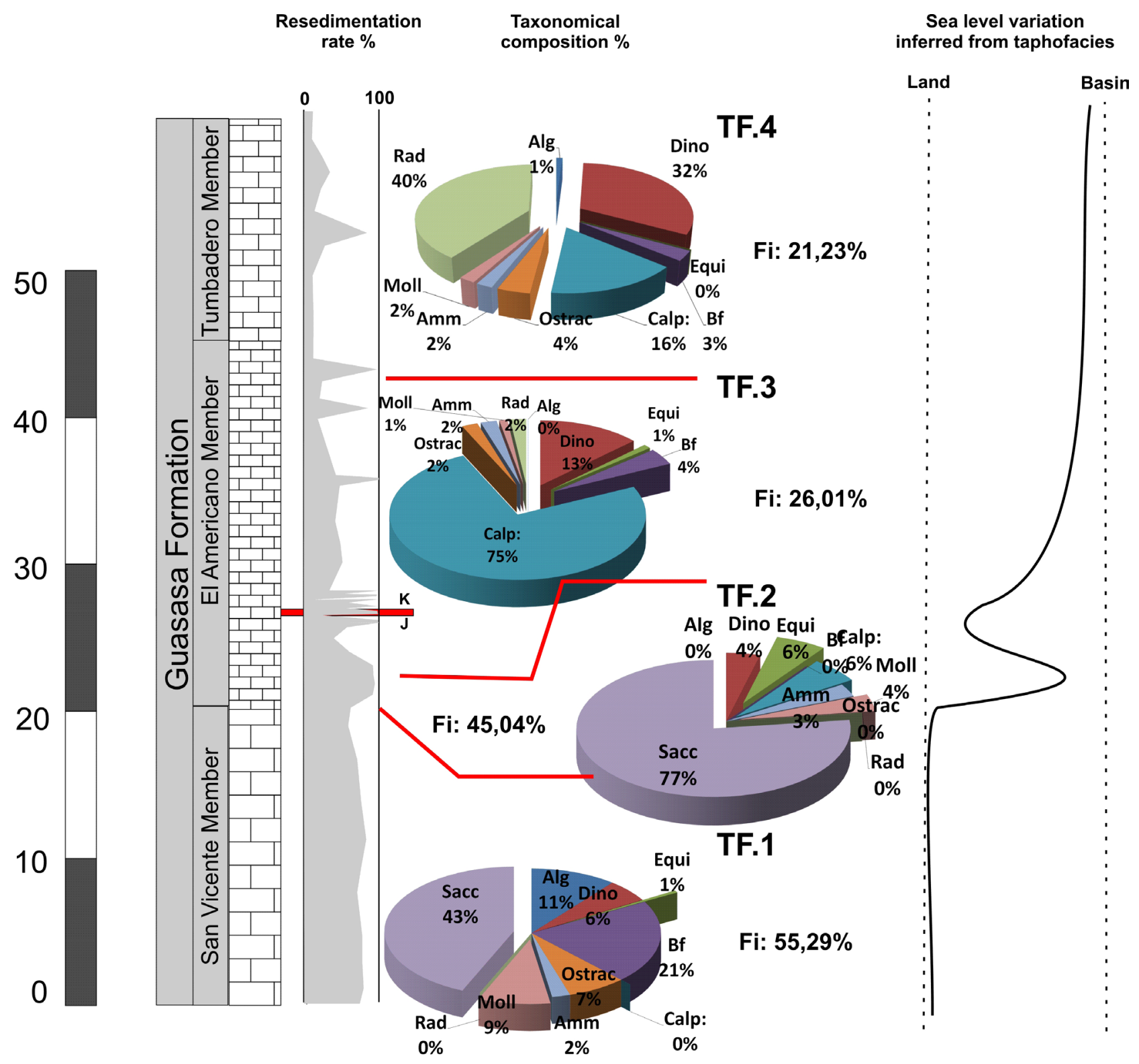

Figure 5. Taphofacies distribution and its characterization, resedimentation rate, taxonomical composition, and fragmentation index (Fi) across the stratigraphic section. Equi: Equinoderm; Dino: Dinocysts; Alg: Algae; Fb: Benthic foraminifers; Calpio: Calpionellids; Ostrac: Ostracods; Rad: Radiolarian; Amm: Ammonite; Moll: Mollusk; Sacc: Saccocomids.

resedimentation, neomorphism, calcite replacement and recrystallization.

The saccocomids are replaced by abundant calpionellids and the process of fragmentation diminishes considerably. The evolution, to a more diverse assemblage, is the response to the establishment of more stable conditions after the drowning of the platform, and is reflected in a decrease in the dominance and an increase in the Shannon and Simpson diversity indexes.

The resedimentation rate is still high but the fragmentation index decreases and is more selective. The high and medium fragmentation degrees are present in large mollusk shells whereas the small fossils like calpionellids and radiolarians remain intact. This fact favors the idea that different assemblages of fossils were continually added to the site of deposition, from adjacent shallower areas through the resedimentation processes. Major variations in the resedimentation rate occur near the Jurassic/Cretaceous boundary associated with the tempestitic condensed levels, and reflect a short term sea level drop.

TF.4: Mainly consists of radiolarians, calcispheres and calpionellids. The taphonomic processes are represented by silica and calcite replacement, resedimentation, pyritization and hematitization. The replacement by silica and calcite plays a negative role in the preservation of the microfossils.

A significant amount of radiolarians in the fossil 
assemblage and the decrease in the fragmentation index linked to a diminished resedimentation rate express a change in the paleoecological and the sedimentation processes.

The bioestratinomical stage produced an association identical to the taphofacies 3; however, taphofacies 4 embraces less resedimented entities due to a minor shallow water influence.

\section{Biodiversity Indexes}

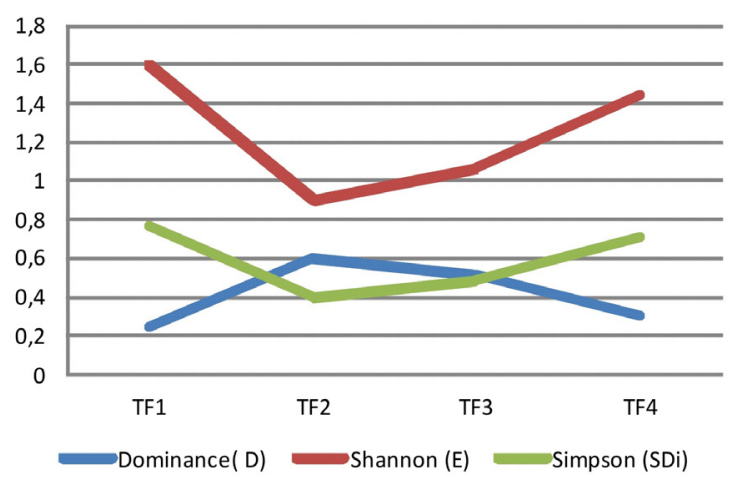

Figure 6. Biodiversity indexes along the taphofacies.

\section{Conclusions}

Four main taphofacies were characterized in the studied section based on different taphonomic processes and features. The characterization of these taphofacies in the stratigraphical sense allows the reconstruction of the general depositional and paleoecological evolution of the original environment (Figure 7).

The interpreted environment along the section is characterized by variations in a general deepening trend, only interrupted by a short-term sea-level drop. Taphofacies 1 corresponds to a shallow water environment with wave action and a mainly benthic community. A sudden change to pelagic conditions reflected in taphofacies 2 caused a disturbance in the paleoecological and sedimentation conditions, resulting in dominance by Saccocoma. Common resedimented entities manifest the frequent action of currents on this taphofacies. The influence of the resedimentation decreases in taphofacies 3 and 4 and shows only sporadic current action in the offshore environment. A sea level drop is recorded in this interval. The high production of organic matter in TF3 responds apparently to upwelling currents that disappear in TF4.

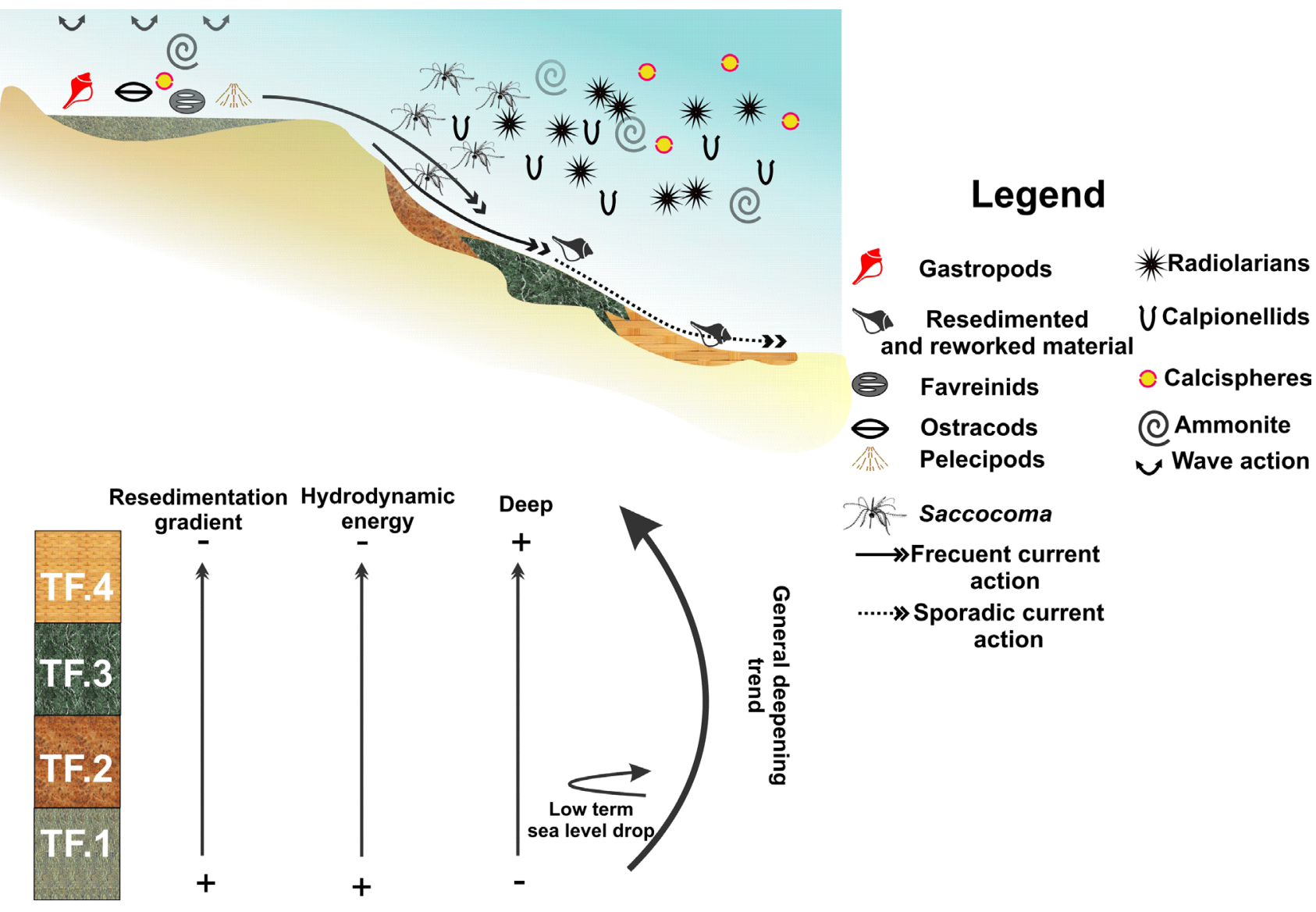

Figure 7. Reconstruction diagrams of the different taphofacies. Not to scale. 
Resedimentation occurs across the studied section. Displaying a general taphonomic cline from the highest resedimentation rates in facies of the San Vicente and the lower parts of the El Americano members, to the lowest levels recorded upwards within the El Americano member.

\section{Acknowledgements}

This study was supported by grants PAPIIT IN109912, DGAPA, UNAM and CONACyT-SEP 177510. Dr. Jorge Luis Cobiella Reguera from the University of Pinar del Río, Cuba is thanked for his help during the fieldwork. The authors express their gratitude to Drs. C. Kendall and Dr. Santantonio and Dra. Sara Alicia Quiroz Barroso whose comments to the first draft of this manuscript served to enhance the quality of the work.

\section{References}

Akihisa, K., 1998, Glaucony and carbonate grains as indicators of the condensed section: Omma Formation, Japan: Sedimentary Geology, $122,151-163$

Cobiella-Reguera, J.L., Oloriz, F., 2009, Oxfordian-Berriasian stratigraphy of the North American paleomargin in western Cuba: Constraints for the geological history of the proto-Caribbean and the early Gulf of Mexico, in Bartolini, C., Román-Ramos, J.R. (eds.), Petroleum systems in the southern Gulf of Mexico: AAPG Memoir 90, 421-451. DOI:10.1306/13191304M903339

De Romero, L.M., Galea-Alvarez, F.A., 1995, Campanian Bolivinoides and microfacies from the La Luna Formation, western Venezuela: Marine Micropaleontology, 26, 385-404.

Efremov, J.A., 1940, Taphonomy: new branch of paleontology: The PanAmerican Geologist, 74, 81-93.

Farinati, E., Spagnoulo, J., Aliotta, S., 2005, Tafonomía comparativa de moluscos en la costa del estuario de Bahía Blanca, Argentina, in Martinell, D. (ed.), 4ta Reunión de Tafonomía y Fosilización: Barcelona, Martinell, D. 105-106.

Fernández-López, S., 1984, Nuevas perspectivas de la Tafonomía evolutiva: tafosistemas y asociaciones conservadas: Estudios Geológicos, 40, 215-224.

Fernández-López, S., 1986, Sucesiones paleobiológicas y sucesiones registráticas (nuevos conceptos paleontológicos): Revista Española de Paleontología, 1, 29-45.

Fernández-López, S., 1988, La Tafonomía: un subsistema conceptual de la Paleontología: Coloquios de Paleontología, 41, 9-34.

Fernández-López, S., 1991a, Sistemas tafonómicos: función y evolución: Revista Española de Paleontología, No extraordinario, 21-34

Fernández-López, S., 1991b, Taphonomic concepts for a theoretical Biochronology: Revista Española de Paleontología, 6, 37-39.

Fernández- López, S., 1991c, Condensación: Significado y aplicaciones al análisis de cuencas: Estudios Geológicos, 47, 169-181.

Flügel, E., 2004, Microfacies of Carbonate Rocks: Analysis, Interpretation, and Application: Heidelberg, Germany, Springer-Verlag, 976 p.

Gómez, J.J., Fernández-López S., 1994, Condensation processes in shallow platforms: Sedimentary Geology, 92, 147-159.
Hagdorn, H., 1982, The "Bank der Kleinen Terbrateln" (Upper Muschelkak, Triassic) Near Scwäbisch Hall (SW- Germany) - a Tempestite Condensation Horizon, in Einsele, G., Seilacher, A. (ed.), Cyclyc and event stratification: Berlin, Springer-Verlag, 263-285.

Hammer, Ø., Harper, D.A.T., 2006, Paleontological data analysis: Malden USA, Blackwell, 368 p.

Herrera, N.H., 1961, Contribución a la estratigrafía de la Provincia de Pinar del Río: Revista de la Sociedad Cubana de Ingenieros, 61, 22-44.

Kelly, J.C., Webb, J.A., 1999, The genesis of glaucony in the OligoMiocene Torquay Group, southeastern Australia: petrographic and geochemical evidence: Sedimentary Geology, 125, 99-114.

Kietzmann, D.A., Palma, R.M., 2010, New crustacean microcoprolites from the Lower Cretaceous (middle Berriasian-lower Valanginian) of the Neuquén Basin, Southern Mendoza, Argentina: Journal of South American Earth Sciences, 30, 58-64.

Kuhry, B., De Clercq, S.W.G., Dekker, L., 1976, Indications of current action in late Jurassic limestones, radiolarian limestones, saccocoma limestones and associated rocks from the subbetic of SE Spain: Sedimentary Geology, 15, 235-258.

McRae, S.G., 1972, Glauconite: Earth Science Reviews, 8, 397-440.

Müller, A.H., 1951, Grundlagen der Biostratonomie: Berlin, Abt. dr. Akad. Wiss, $147 \mathrm{p}$

Olóriz, F., Reolid, M., Rodriguez-Tovar, F.J., 2002, Fossil assemblages, lithofacies and taphofacies for interpreting depositional dynamics in epicontinental Oxfordian (Prebetic Zone, Betic Cordillera, southern Spain): Palaeogeography, Palaeoclimatology, Palaeoecology, 185, 53-75.

Olóriz, F., Matías, R., Rodríguez-Tovar, F.J., 2004, Microboring and taphonomy in Middle Oxfordian to lowermost Kimmeridgian (Upper Jurassic) from the Prebetic Zone (southern Iberia): Palaeogeography, Palaeoclimatology, Palaeoecology, 212, 181-197. Müller, A. H., 1951, Grundlagen der Biostratonomie. Berin, Abhandlungen der deutsche Akademische Wissenschaft. 147p.

Pszczólkowski, A., Myczynski, R., 2010, Tithonian-Early Valanginian evolution of deposition along the proto-Caribbean margin of North America recorded in Guaniguanico successions (western Cuba): Journal of South American Earth Sciences, 29, 225-253.

Schweigert, G., Seegis, D.B., Fels, A., Leinfelder, R., 1997, New internally structured decapod microcoprolites from Germany (Upper Triassic/Lower Miocene), southern Spain (Lower/Middle Jurassic) and Portugal (Upper Jurassic); taxonomy, palaeoecology and evolutionary implications: Paläontologische Zeitschrift, 71, 51-69.

Seilacher, A., 1982, General remarks about event deposits, in Einsele G., Seilacher A. (eds.), Cyclic and event stratification: Berlin, SpringerVerlag, 161-174

Simpson, E.H., 1949, Measurement of diversity: Nature, 163, 688-688.

Tasch, P., 1973, Paleobiology of the Invertebrates. Data retrieval from the Fossil Record: New York, Wiley and Sons, 975 p.

Weigelt, J., 1927, Rezente Wirbeltierleichen und ihre palaobiologische Bedeutung: Leipzig, Verlag M. Weg, 188 p.

Manuscript received: July 25, 2013.

Corrected manuscript received: August 12, 2013.

Manuscript accepted: August 14, 2013. 